\title{
Functional characterization of a biosurfactant-producing thermo-tolerant bacteria isolated from an oil reservoir
}

\author{
Wang Jing ${ }^{1 *}$, Ji Guang ${ }^{1}$, Tian Jing ${ }^{1}$, Zhang Hongdan ${ }^{1}$, Dong Hanping ${ }^{2}$ and \\ $\mathbf{Y u ~ L i}{ }^{2}$ \\ ${ }^{1}$ College of Chemical Engineering, China University of Petroleum, Beijing 102249, China \\ ${ }^{2}$ Langfang Branch, Research Institute of Petroleum Exploitation and Development, China National Petroleum Corporation, \\ Hebei 065007, China
}

(C) China University of Petroleum (Beijing) and Springer-Verlag Berlin Heidelberg 2011

\begin{abstract}
A Bacillus subtilis strain JA-1 isolated from an oil reservoir was studied. This strain is capable of growth and producing biosurfactant at a temperature of $60{ }^{\circ} \mathrm{C}$. In nutrient medium it produced biosurfactant which reduced the surface tension from $68.2 \mathrm{mN} / \mathrm{m}$ to $28.3 \mathrm{mN} / \mathrm{m}$, with the critical micelle concentration (CMC) of $48 \mathrm{mg} / \mathrm{L}$. The measured surface tension indicated that the biosurfactant possessed stable surface activity at high temperature and a specific range of $\mathrm{pH}$ and salt concentrations. The results of thin layer chromatography (TLC) together with FT-IR showed that the metabolic product of strain JA-1 is a lipopeptide biosurfactant. The ability to growth at high temperature and to produce biosurfactant makes strain JA-1 promising for enhanced oil recovery.
\end{abstract}

Key words: Biosurfactant, bacillus subtilis, lipopeptide, surface tension, critical micelle concentration $(\mathrm{CMC})$

\section{Introduction}

Biosurfactants are surface-active amphipathic molecules produced by a wide variety of microorganisms. Biosurfactants possess many unique properties, such as low toxicity, high biodegradability, good environmental compatibility, high foaming and high selectivity. They do not lose physicochemical properties at different temperatures and $\mathrm{pH}$ levels (Mulligan, 2005), and can be synthesized using waste substrate (Benincasa and Accorsini, 2008). These advantages allow biosurfactants to be a substitute for chemically synthesized surfactants, and they are widely used in food, cosmetics, pharmaceuticals, agricultural, and petrochemical industries(Remichkova et al, 2008; Pruthi and Cameotra, 2003; Abouseou et al, 2008). Many microorganisms, such as bacteria, fungi and yeasts, have the ability to produce biosurfactants (Deshpande and Daniels, 1995; Ghojavand et al, 2008; Kiran et al, 2009; Nayak et al, 2009). Biosurfactants produced by microorganisms have a wide structural diversity, including glycolipids, lipopeptides, lipoproteins, fatty acids, neutral lipids, phospholipids, polymeric and particulate biosurfactants (Desai and Banat, 1997).

Microbial enhanced oil recovery (MEOR) is an important

*Corresponding author: email: swhgwj898@cup.edu.cn Received December 15, 2010 tertiary oil recovery technology, in which microbial cells or their metabolites were utilized (Youssef et al, 2007). As the metabolites produced by microorganisms, biosurfactants have the ability to emulsify crude oil and to decrease the viscosity of crude oil, which is one of the mechanisms for MEOR (Bognolo, 1999). Environmental conditions in oil reservoirs are usually harsh and severe, so microorganisms which can grow easily in the oil reservoir and produce biosurfactants will be significant for MEOR process.

This paper presents the characteristics of a biosurfactantproducing strain with promising potential for MEOR. The physicochemical properties such as surface activity and emulsification activity were investigated. Specially, the influences of some environmental conditions, i.e., $\mathrm{pH}$, temperature and salinity were investigated. Identification of the types and study of its characteristics, of extracted biosurfactants was conducted as well.

\section{Materials and methods}

\subsection{Materials}

B. subtilis JA-1, previously identified and isolated from an oil reservoir, was used for production of biosurfactant. The culture was maintained on Luria-Bertani (LB) agar slant at 4 ${ }^{\circ} \mathrm{C}$. All the reagents used in this study were purchased from the Beijing Chemical Reagent Factory, China. 


\subsection{Culture medium and conditions}

The nutrient medium contained of the following components $(\mathrm{g} / \mathrm{L})$ : Glucose, $20 ; \mathrm{NaCl}, 2 ; \mathrm{NH}_{4} \mathrm{NO}_{3}, 1$; $\mathrm{Na}_{2} \mathrm{HPO}_{4}, 2 ; \mathrm{KH}_{2} \mathrm{PO}_{4}, 4 ; \mathrm{FeSO}_{4} \cdot 7 \mathrm{H}_{2} \mathrm{O}, 0.01 ; \mathrm{MgSO}_{4} \cdot 7 \mathrm{H}_{2} \mathrm{O}$, $0.05 ; \mathrm{MnSO}_{4}, 0.01$; yeast extract, 0.2 and urea, 0.5. The $\mathrm{pH}$ was adjusted to 7.0 with $\mathrm{HCl}$ or $\mathrm{NaOH}$ solution.

The strain JA-1 was first grown overnight at $37^{\circ} \mathrm{C}$ on nutrient agar plates. Then one loop of culture was inoculated in $50 \mathrm{~mL}$ of LB in a $150 \mathrm{~mL}$ flask and incubated in a rotary shaker at $160 \mathrm{rpm}$ and $37^{\circ} \mathrm{C}$ for $18 \mathrm{~h}$. After that, $5 \mathrm{~mL}$ aliquot of the inoculum was transferred to $100 \mathrm{~mL}$ fresh nutrient medium. The reaction mixture was incubated under the same conditions.

\subsection{Analytical methods}

\subsubsection{Measurement of biomass}

The culture sample was centrifuged at 12,000 rpm for $10 \mathrm{~min}$, and the cell-free broth was removed, then an equal volume of distilled water was used to suspend the bacteria cells. The biomass concentration of the bacteria cells was determined with an UV spectrophotometer (UV-2000, Unico, USA) at $600 \mathrm{~nm}$ (OD600).

\subsubsection{Measurement of surface tension}

Culture samples were centrifuged at $12,000 \mathrm{rpm}$ for 10 $\min$ to remove the bacteria cells, and the surface tension of the cell-free broth was determined with a tensiometer (JK99B, Powereach, China) by the plate method at room temperature.

\subsubsection{Measurement of emulsification index (E24)}

The measurement of emulsification index (E24) is a rapid and reliable way to determine the quantity of biosurfactant. It was performed according to the method of Cooper and Goldenberg (1987). Aqueous solution (4 mL) of biosurfactant was mixed with $6 \mathrm{~mL}$ hydrocarbon in a screw-capped glass tube, and shaken with a vortex for $2 \mathrm{~min}$, then left to stand for $24 \mathrm{~h}$ prior to measurement. The emulsification index was calculated as follows: The height of emulsion layer is dividend by the total height of the mixture and then multiplied by $100 \%$.

\subsection{Effect of $\mathrm{pH}$, temperature and salinity on biosurfactant stability}

The effect of $\mathrm{pH}$, temperature and salinity on the surface activity of biosurfactant was studied to evaluate the stability of biosurfactant with changing ambient conditions. Stability studies were carried out using the cell-free broth obtained after $48 \mathrm{~h}$ of cultivation by centrifuging the cultures at 9000 $\mathrm{r} / \mathrm{m}$ for $20 \mathrm{~min}$. The $\mathrm{pH}$ of cell-free broth was adjusted to 2 , $4,6,7,8,10$ and 12 with $\mathrm{HCl}$ or $\mathrm{NaOH}$ solutions; Four mL of the cell-free broth were incubated at each of 4, 37, 50, 75, 100 and $121^{\circ} \mathrm{C}$ for $30 \mathrm{~min}$ and then kept at room temperature; The salinity of cell-free broth was adjusted to $2,4,6,8,10,12,15$ and $20 \mathrm{~g}(\mathrm{NaCl}) \cdot \mathrm{L}^{-1}$. The surface tension and emulsification index of these cell-free broths were measured.

\subsection{Emulsification activity of biosurfactant against hydrocarbons}

Different hydrocarbons were separately mixed with cellfree broth to test the emulsification activity of biosurfactant.
The emulsification index (E24) was measured as described above in section 2.3.3.

\subsection{Extraction and chemical identification of biosurfactant}

Characterization of the biosurfactant was conducted by thin layer chromatography (TLC) as reported (Li et al, 2008). Crude biosurfactant was dissolved in methanol and spotted on silica plates using $\mathrm{CHCl}_{3}: \mathrm{CH}_{3} \mathrm{OH}: \mathrm{H}_{2} \mathrm{O}(65: 15: 1, \mathrm{v} / \mathrm{v} / \mathrm{v})$ as the developing solvent system. After the solvent was evaporated, the plate was then sprayed with $0.2 \%(\mathrm{w} / \mathrm{v})$ ninhydrin in acetone, heated at $110^{\circ} \mathrm{C}$ for $20 \mathrm{~min}$. The plate was kept at room temperature to cool down, then placed in a sealed bottle which in which a small tube of $1.0 \mathrm{~mL}$ concentrated $\mathrm{HCl}$ had been placed at the bottom in advance and heated at $110{ }^{\circ} \mathrm{C}$ for $1.5 \mathrm{~h}$. Again, $0.2 \%(\mathrm{w} / \mathrm{v})$ ninhydrin in acetone was applied and the plate was heated at $110{ }^{\circ} \mathrm{C}$ for $20 \mathrm{~min}$. Biosurfactant was separated and purified by the method reported (Cooper et al, 1981). Fourier transform infrared (FT-IR) spectroscopy of the biosurfactants was recorded on a spectrometer $(113 \mathrm{~V}$, Bruker, Germany) by the $\mathrm{KBr}$ pellet method. About $2 \mathrm{mg}$ of dried crude biosurfactant was milled with $200 \mathrm{mg}$ of $\mathrm{KBr}$ to form a very fine powder. This powder was then compressed into a thin pellet which was analyzed by FT-IR spectroscopy in range of 4,000-400 $\mathrm{cm}^{-1}$ (Lotfabad et al, 2009).

\subsection{Measurement of critical micelle concentration (CMC)}

$\mathrm{CMC}$ is an important parameter in the evaluation of biosurfactant activity. The CMC value is determined based on the fact that after the micelles are formed, the surface tension does not decrease with increasing biosurfactant concentration (Cooper and Zajic, 1980). The surface tension of different concentrations of biosurfactant in distilled water was measured at room temperature. The $\mathrm{CMC}$ was detected by observing the biosurfactant concentrations at which the surface tension first became minimum.

\section{Results and discussion}

\subsection{Effect of temperature on growth and biosurfactant production of JA-1}

An aliquot of $5 \mathrm{~mL}$ overnight pre-culture of the strain JA1 was transferred to $250 \mathrm{~mL}$ flasks containing $100 \mathrm{~mL}$ nutrient medium and incubated at different temperatures, and stirred at $160 \mathrm{rpm}$ for $30 \mathrm{~h}$. The results (see Table 1) showed that JA-1 can grow well and produce biosurfactant at temperatures of $30-50{ }^{\circ} \mathrm{C}$, biomass and biosurfactant production reached maximum at $40{ }^{\circ} \mathrm{C}$. At $60{ }^{\circ} \mathrm{C}$, the strain JA-1 remained alive, but it produced only a small amount of biosurfactant.

Table 1 Effect of temperature on growth and biosurfactant production of JA-1

\begin{tabular}{ccccc}
\hline \multirow{2}{*}{ Growth condition } & \multicolumn{4}{c}{ Temperature, ${ }^{\circ} \mathrm{C}$} \\
\cline { 2 - 5 } & 30 & 40 & 50 & 60 \\
\hline Biomass $\left(\mathrm{OD}_{600}\right)$ & 1.79 & 4.39 & 1.58 & 0.53 \\
Biosurfactant production, $\mathrm{g} / \mathrm{L}$ & 0.26 & 0.32 & 0.18 & 0.04 \\
\hline
\end{tabular}




\subsection{Effect of pH, salinity and temperature on biosurfactants tability}

The effect of $\mathrm{pH}$ on biosurfactant activity is shown in Fig. 1a. It can be seen that the $\mathrm{pH}$ range of 7-8, was optimal for both the biosurfactant activity and its emulsification capacity. In this $\mathrm{pH}$ range the surface tension reached the lowest value of $28 \mathrm{mN} / \mathrm{m}$ and E24 reached the highest value of $75 \%$. When $\mathrm{pH}$ varied from 6 to 2 , both the biosurfactant activity and its emulsification capacity decreased. E24 decreased sharply to $8 \%$ at $\mathrm{pH} 2$ and the reason might be that biosurfactant was precipitated from the broth. At pH 10 and 12, E24 also decreased a little, however the surface tension was relatively stable. Fig. $1 \mathrm{~b}$ shows that the change in surface tension was not significant with increasing $\mathrm{NaCl}$ concentration up to $14 \%$ $(\mathrm{w} / \mathrm{v})$, and an increasing $\mathrm{NaCl}$ concentration up to $8 \% \mathrm{did}$ not cause significant effect on E24. However, E24 dropped steeply when $\mathrm{NaCl}$ concentration increased from $8 \%$ to $10 \%$. Fig. 1c shows that the surface tension and E24 of the cellfree broth changed little in the temperature range of $4-121{ }^{\circ} \mathrm{C}$, indicating that the biosurfactant was thermostable and that the biosurfactant produced by strain JA-1 can be applied in a wide temperature range.
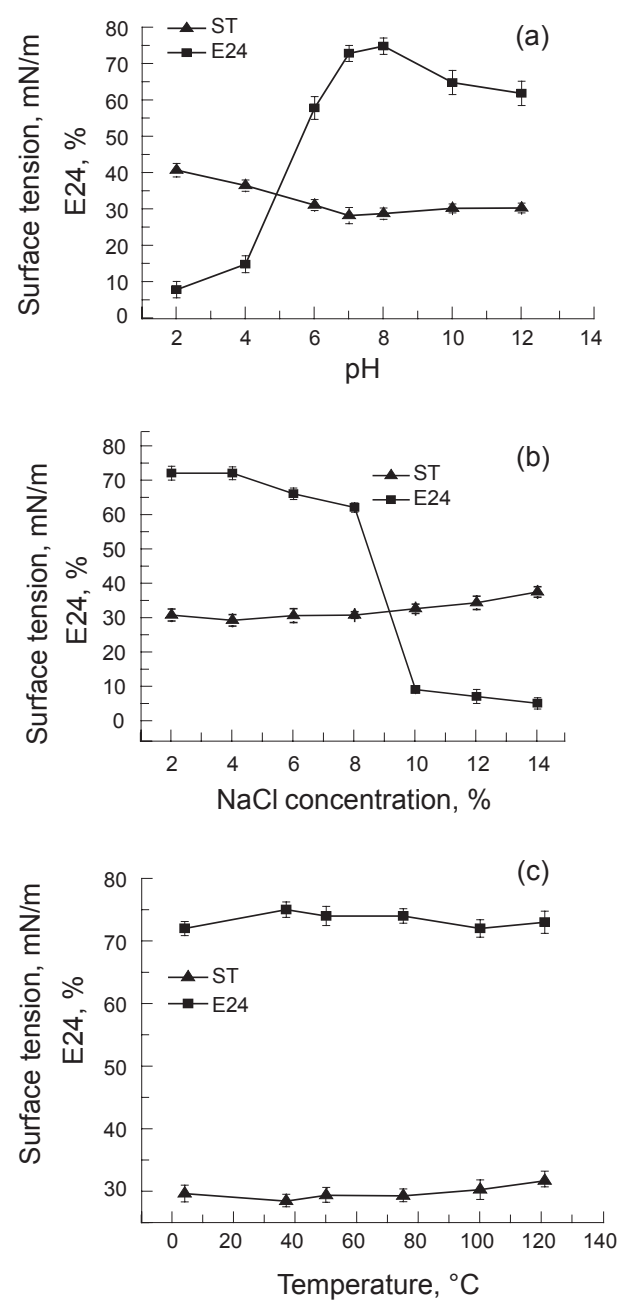

Fig. 1 Effect of $\mathrm{pH}$, salinity and temperature on the stability of biosurfactant

\subsection{Emulsification activity of biosurfactant on hydrocarbons}

Besides surface activity, good emulsification property is also critical for biosurfactants to be used in different environments and industrial applications (Banat et al, 2000). Fig. 2 shows the experimental results on the emulsification activity of biosurfactant. It can be seen that the biosurfactant produced by strain JA-1 is capable of forming stable waterin-oil emulsions with all the hydrocarbons used.

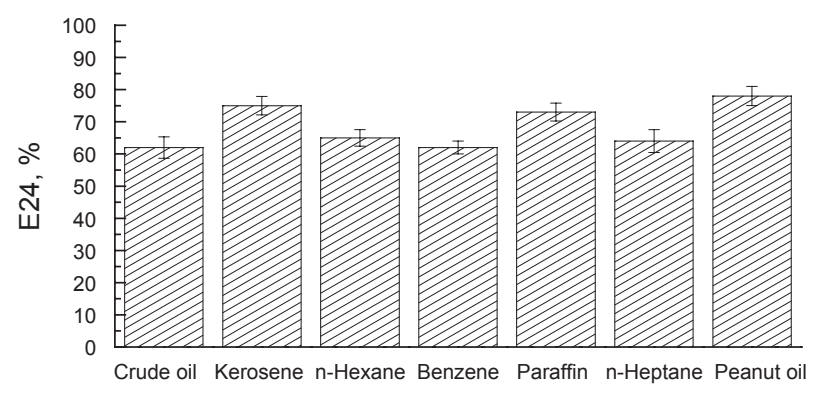

Fig. 2 Emulsification activity (E24) of biosurfactant on hydrocarbons

\subsection{Critical micelle concentration (CMC) of biosurfactant}

As shown in Fig. 3, the surface tension of biosurfactant decreased as its concentration increased until the concentration reached $48 \mathrm{mg} / \mathrm{L}$. At this point, the surface tension decreased to the lowest $28.3 \mathrm{mN} / \mathrm{m}$, and did not decrease further with increasing concentration, then the $\mathrm{CMC}$ was determined to be $48 \mathrm{mg} / \mathrm{L}$. Compared with sodium dodecyl sulfate (SDS) which has a CMC value of $2,100 \mathrm{mg} / \mathrm{L}$ (Chen et al, 2006), the CMC of JA-1 was much lower.

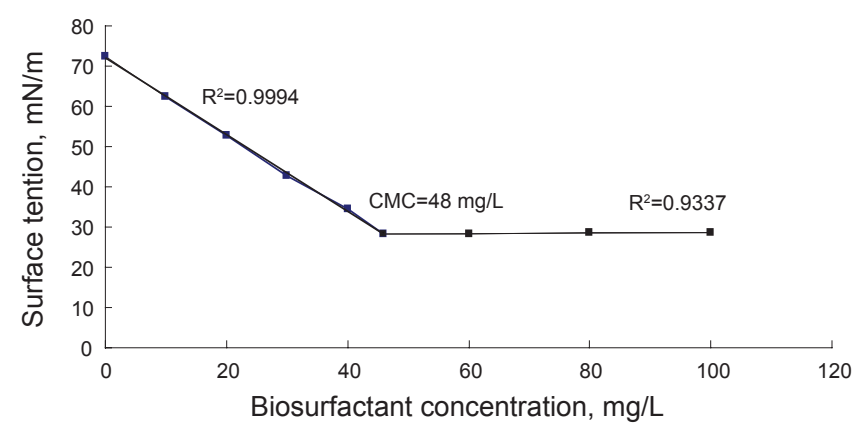

Fig. 3 The CMC of biosurfactant produced from JA-1

\subsection{Chemical characterization of biosurfactant produced by strain $\mathrm{JA}-1$}

It is known that free amino acids are colored when reacted with ninhydrin solution. Cyclic or linear peptides are broken down to free amino acids in the presence of concentrated $\mathrm{HCl}$ at high temperature and then colored by ninhydrin solution (Li et al, 2008). TLC analysis of crude biosurfactant showed that no spots were found on the silica plate before hydrolysis, but red color spots appeared after hydrolysis, indicating that this biosurfactant did not contain free amino acids but cyclic peptides. 
Fig. 4 shows the FT-IR spectrum of biosurfactant produced by JA-1 in $\mathrm{KBr}$. It can be seen that the characteristic bands at 3,310 $\mathrm{cm}^{-1}$ (NH stretching mode) and at $1,657 \mathrm{~cm}^{-1}$ (stretching mode of the $\mathrm{CO}-\mathrm{N}$ bond) are assigned to peptides.
The bands at 2,958-2,927 $\mathrm{cm}^{-1}, 2,871-2,850 \mathrm{~cm}^{-1}$ and at 1,467 $\mathrm{cm}^{-1}, 1,402 \mathrm{~cm}^{-1}$ are assigned to aliphatic chains $\left(-\mathrm{CH}_{3}\right.$, ${ }_{-}^{-} \mathrm{CH}_{2}{ }^{-}$), and a band observed at $1,737 \mathrm{~cm}^{-1}$ corresponds to a carbonyl group. These results suggest that the biosurfactant

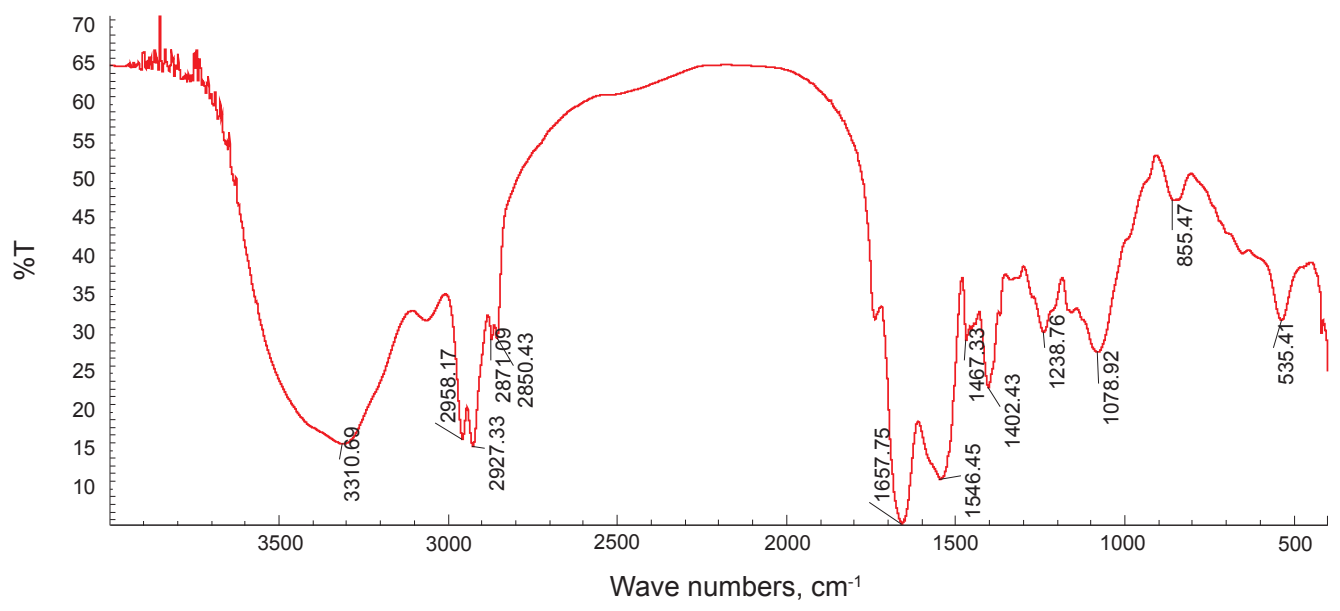

Fig. 4 FT-IR spectrum of surfactant produced by JA-1

contains aliphatic hydrocarbons and carbonyl moieties.

\section{Conclusions}

In this paper, the production of the biosurfactant from a Bacillus subtilis JA-1 was reported. Physical properties, i.e. the surface tension, $\mathrm{CMC}$ and emulsification activity, and the stability to salinity, $\mathrm{pH}$ and temperature of the biosurfactant were studied. Compared with chemically synthesized biosurfactant, the value of its CMC is very low. Both the strain and its production have good tolerance to environmental stresses. The stable surface activity at high temperature and a specific range of salt concentrations meets the criterion that the biosurfactant need to be stable under the extreme environmental conditions encountered in the oil reservoir during the MEOR process.

\section{Acknowledgements}

This work is supported by the National High-technology Research and Development Program (863 Program) of China (Grant No. 2009AA063504), China National Petroleum Corporation Science \& Technology Management Program (2008A-1403).

\section{References}

Abouseoud M, Maachi R, Amrane A, et al. Evaluation of different carbon and nitrogen sources in production of biosurfactant by Pseudomonas fluorescens. Desalination. 2008. 223(1-3): 143-151

Banat I M, Makkar R S and Cameotra S S. Potential commercial applications of microbial surfactants. Appl. Microbiol. Biotechnol. 2000. 53(5): 495-508

Benincasa $\mathrm{M}$ and Accorsini F R. Pseudomonas aeruginosa LBI production as an integrated process using the wastes from sunfloweroil refining as a substrate. Bioresource Technol. 2008. 99: 3843-3849

Bognolo G. Biosurfactants as emulsifying agents for hydrocarbons. Colloids Surf. A: Physico. Chem. Eng. Aspects. 1999. 152 (1-2): 41 52

Chen J. Wang X J, Hu J D, et al. Effect of surfactants on biodegradation of PAHs by white-rot fungi. Environ Sci. 2006. 27(1): 154-159

Cooper D G and Goldenberg B G. Surface-active agents from two
Bacillus species. Appl. Environ. Microbiol. 1987. 53(2): 224-229

Cooper D G, Macdonald C R, Duff S J B, et al. Enhanced production of surfactin from Bacillus subtilis by continuous product removal and metal cation additions. Appl. Environ. Microbiol. 1981. 42(3): 408412

Cooper D G and J E Zajic. Surface active compounds from microorganisms. Adv. Appl. Microbiol. 1980. 26: 229-253

Desai J D and Banat I M. Microbial production of surfactants and their commercial potential. Microbiol Mol Biol Rev. 1997. 61(1): 47-48

Deshpande M and Daniels L. Evaluation of sophorolipid biosurfactant production by Candida bombicola using animal fat. Bioresour. Technol.1995. 54(2): 143-150

Ghojavand H, Vahabzadeh F, Roayaei E, et al. Production and properties of a biosurfactant obtained from a member of the Bacillus subtilis group (PTCC 1696). J Colloid Interface Sci. 2008. 324(1-2): 172176

Kiran G S, Hema T A, and Gandhimathi R. Optimization and production of a biosurfactant from the sponge-associated marine fungus Aspergillus ustus MSF3. Colloids and Surfaces B: Biointerfaces. 2009. 73(2): 250-256

Li Y M, Haddad N I A, Yang S Z, et al. Variants of lipopeptides produced by Bacillus licheniformis HSN221 in different medium components evaluated by a rapid method ESI-MS. Int J Pept Res Ther. 2008. 14: 229-235

Lotfabad T B, Shourian M and Roostaazad R. An efficient biosurfactantproducing bacterium Pseudomonas aeruginosa MR01, isolated from oil excavation areas in south of Iran. Colloids and Surfaces B: Biointerfaces. 2009. 69(2): 183-193

Mulligan C N. Environmental applications for biosurfactants. Environ. Pollut. 2005. 133:183-198

Nayak A S, Vijaykumar M H and Karegoudar T B. Characterization of biosurfactant produced by Pseudoxanthomonas sp. PNK-04 and its application in bioremediation. International Biodeterioration \& Biodegradation. 2009. 63(1): 73-79

Pruthi V and Cameotra S S. Effect of nutrients on optimal production of biosurfactants by Pseudomonas putida - A Gujarat oil field isolate. Journal of Surfactants and Detergents. 2003. 6(1): 65-68

Remichkova M, Galabova D, Roeva I, et al. Anti-herpesvirus activities of Pseudomonas sp. S-17 rhamnolipid and its complex with alginate. Z Naturforsch C. 2008. 63: 75-81

Youssef N, Simpson D R, Duncan K E, et al. In situ biosurfactant production by Bacillus strains injected into a limestone petroleum reservoir. Appl. Environ. Microbiol. 2007. 73(4): 1239-1247

(Edited by Zhu Xiuqin) 